BULLETIN Bulletin hispanique

HISPANIQUE Université Michel de Montaigne Bordeaux

118-1 | 2016

La Guerre Civile espagnole aujourd'hui (1936-2016)

\title{
Bartolomé de Torres Naharro, Teatro completo, edición de Julio Vélez-Sainz
}

Cátedra, Madrid, 2013

Ignacio López Alemany

\section{(2) OpenEdition}

Journals

Edición electrónica

URL: http://journals.openedition.org/bulletinhispanique/4434

DOI: 10.4000/bulletinhispanique.4434

ISSN: 1775-3821

Editor

Presses universitaires de Bordeaux

Edición impresa

Fecha de publicación: 15 julio 2016

Paginación: 367-369

ISBN: 979-10-300-0058-0

ISSN: 0007-4640

Referencia electrónica

Ignacio López Alemany, « Bartolomé de Torres Naharro, Teatro completo, edición de Julio Vélez-Sainz », Bulletin hispanique [En línea], 118-1 | 2016, Publicado el 15 julio 2016, consultado el 23 septiembre 2020. URL : http://journals.openedition.org/bulletinhispanique/4434 ; DOI : https://doi.org/10.4000/ bulletinhispanique.4434

Este documento fue generado automáticamente el 23 septiembre 2020

Tous droits réservés 


\section{Bartolomé de Torres Naharro, Teatro completo, edición de Julio Vélez- Sainz}

Cátedra, Madrid, 2013

Ignacio López Alemany

\section{REFERENCIA}

Bartolomé de Torres Naharro, Teatro completo, edición de Julio Vélez-Sainz, Madrid, Cátedra, 2013, 1104 p. (colección: Letras Hispánicas, 728) ISBN: 978-84-376-3177-6.

1 A Bartolomé de Torres Naharro (1485-1520) le corresponde la publicación de la primera preceptiva teatral en lengua romance de la que tenemos constancia y su obra dramática alcanzó una difusión impresa durante el siglo XVI que superaría con creces la de otros dramaturgos de la talla de Juan del Encina, Gil Vicente o Lope de Rueda. Sin embargo, desde la magna edición de Joseph E. Gillet de Propalladia and Other Works of Bartolomé de Torres Naharro a mediados del siglo pasado, esta que ahora comentamos es la primera edición crítica moderna del teatro completo del autor palentino. Ciertamente, casi podría parecer que el rigor del trabajo monumental del filólogo norteamericano habría acallado -ahogado- todo posible debate sobre la composición y transmisión textual de la Propalladia. Por este, acometer un trabajo de semejante envergadura parecería propio de una osadía casi quijotesca y, sin embargo, el editor, Julio Vélez-Sainz, sale triunfador de este difícil lance.

El volumen está dividido en varias secciones que se inician con una amplia «Introducción» en la que se repasa la vida y semblanza literaria del autor, un estudio de la Propalladia, las fuentes utilizadas por Torres Naharro para la confección de su preceptiva teatral, algunas notas sobre la praxis escénica, aparataje introductorio y la recepción de su obra en su tiempo. A continuación, encontramos un segundo apartado denominado «Esta edición» en el que se hace una breve historia de la fortuna editorial 
de la Propalladia y las publicaciones de comedias sueltas, la fijación del stemma y del codex optimus de las comedias Calamita y Aquilana, que no aparecen en la edición de la Propalladia de 1517. Para cerrar esta unidad, se detallan los criterios que se han empleado en esta edición para facilitar la lectura del texto original. En el tercer aparatado se encuentra la bibliografía y, justo después, la sección de «Teatro completo», en la que se pueden leer las obras organizadas según «lo que creemos sería la ordenación del impreso de Sevilla de 1520» (155). Esto es: Comedia Serafina, Comedia Trofea, Comedia Soldadesca, Comedia Tinelaria, Comedia Himenea, Comedia Jacinta, Diálogo del nacimiento y Adición del Diálogo, Comedia Calamita y Comedia Aquilana. Cada una de estas obras se encuentra precedida por una breve introducción y resumen de la obra. A continuación se recogen dos apéndices, uno dedicado a paratextos de distintas sueltas y ediciones de la Propalladia y otro en el que se recogen las «Notas previas a Terencio» de Josse Bade de Asche que le resultarán muy útiles al lector para poder seguir las reflexiones de Julio Vélez-Sainz acerca del Proemio. Las últimas páginas se dedican a «Agradecimientos» y un «Índice de palabras comentadas en nota y glosario de palabras comunes».

3 A pesar de los pocos datos ciertos que tenemos de la biografía de Bartolomé de Torres Naharro, gracias a una minuciosa lectura e interpretación de los paratextos de la edición de la Propalladia de 1517 en su contexto cortesano y de mecenazgo, Vélez-Sainz consigue en su «Introducción» presentarnos una semblanza satisfactoria tanto en lo estrictamente biográfico como en lo que se refiere al método de composición de nuestro autor, su posicionamiento dentro del campo literario de su época y su preocupación por declarar la preceptiva que rige sus composiciones dramáticas. En efecto, la reflexión acerca de poética dramática que Torres lleva a cabo en su Proemio es algo completamente excepcional entre los autores de su tiempo. Si bien su preceptiva no es, quizá, excesivamente original, tal y como puede desprenderse de la lectura del extenso estudio que le dedica el editor a la luz de las Notas previas a Terencio de Josse Bade de Asche.

4 Es muy de agradecer la inclusión en este estudio y edición de sendas secciones dedicadas a la praxis escénica y a la praxis dramática de Torres Naharro, lo que denota un interés por parte del editor por ubicar al autor pacense no únicamente en su dimensión literaria sino también en su aspecto performativo tanto en lo que tiene como heredero de una tradición latina como en lo que tiene de original y constituye su legado al teatro del Renacimiento español. Esto es: la utilización del verso con coplas de cinco versos de pie quebrado; la división de la comedia en cinco «jornadas» (así como la propia denominación de «jornadas»); la profesionalización de los actores; la presencia de introitos y argumentos al comienzo de las comedias; la comedia de costumbres; el énfasis en la unidad de acción y la popularización del modelo escénico de Vitruvio (106).

5 Encontramos en esta edición una fructífera combinación de respeto al magisterio de Joseph E. Gillet, Humberto López Morales, E. W. McPheeters y Miguel Ángel Pérez Priego y una voz crítica propia que no duda en asumir elementos de unos y otros, pero que no vacila en apartarse de todos ellos cuando así lo considera acertado. Así, por ejemplo, si en los criterios ortográficos se encuentra más cercano a McPheeters, en la puntuación está más próximo a Pérez Priego, y sigue a Gillet en su decisión de dividir las escenas y señalar los apartes, «pues puede resultar de gran utilidad para posibles adaptaciones contemporáneas» (154). Preocupación esta -la representabilidad de los 
textos- muy presente a lo largo de esta edición. Sin embargo, para la fijación del texto de la Comedia Calamita, al contrario que Gillet -que únicamente utiliza la edición de Cromberger de 1533 como texto base-, Vélez-Sainz apuesta por la utilización de las dos ediciones salidas de aquella prensa sevillana, toda vez que ahora se ha podido leer $y$ comprobar que el colofón parcialmente borrado de la edición rechazada por el norteamericano pertenece al año 1526 y, por consiguiente, se trata de una edición más cercana al autor (140). Más complejo aún es dilucidar el stemma de la Comedia Aquilana, pero Vélez-Sainz justifica convincentemente el abandono de la edición napolitana de 1524 como texto base único (tal y como han hecho el resto de los editores modernos) para defender la necesidad de utilizar otros testimonios con los que reconstruir el arquetipo original de la obra «a partir del esquema neolachmanniano» (146).

6 La experiencia de lectura de las comedias en sí es ciertamente agradable. A esto ayuda la presentación de las comedias precedidas de una breve introducción y un resumen por jornadas. Asímismo, también contribuye a la fácil lectura la impresión de una tabla de personajes debajo del título, la breve acotación acerca del lugar en el que tiene lugar la acción y, sobre todo, la ubicación del aparato de variantes al final de cada comedia. No hay en los propios versos de la comedia una llamada que indique la existencia de variantes, sino que es en el listado final donde encontramos en qué versos varían los distintos testimonios. Si bien es cierto que esto puede molestar a algunos lectores, esta distribución simplifica y facilita la lectura académica de las comedias sin perjudicar otras lecturas, quizá más minoritarias, que tengan especial interés por el cotejo de las variantes textuales. Así, durante la lectura de las comedias, las notas a pie de página únicamente tienen una función explicativa tanto de tipo lingüístico como cultural y, en raras ocasiones, de traducción de alguna expresión o verso.

7 En resumidas cuentas, la presente edición del Teatro completo de Bartolomé de Torres Naharro recupera para el público académico la obra de un autor clave para entender el teatro del Renacimiento español. La inteligencia y minuciosidad con que se han estudiado los textos, así como el especial cuidado puesto sobre el carácter dramático de los textos literarios son, además, un ejemplo y modelo a seguir para futuras ediciones de textos teatrales en este siglo veintiuno.

\section{AUTORES}

\section{IGNACIO LÓPEZ ALEMANY}

University of North Carolina at Greensboro 